\title{
INTRODUCTION \\ THE UNIVERSAL LANGUAGE OF INTERNATIONAL SECURITIZATION
}

\author{
STEVEN L. SCHWARCZ*
}

On behalf of the Duke University Global Capital Markets Center, which is sponsoring this symposium, I am pleased to welcome readers to the symposium issue. The focus is on international securitization, an increasingly important area of cross-border finance. This article introduces the reader to international securitization, first by explaining the concepts of securitization and then by examining securitization in a cross-border context.

\section{CONCEPTS OF SECURITIZATION}

In a securitization, a company partly "deconstructs" itself by separating certain types of highly liquid assets from the risks generally associated with the company. ${ }^{1}$ The company then can use these assets to raise funds in the capital markets ${ }^{2}$ at a lower cost than if the company, with its associated risks, had raised the funds directly by issuing debt or equity. The company retains the savings generated by these

Copyright (C) 2002 by Steven L. Schwarcz

* Professor of Law, Duke University School of Law; Faculty Director, Duke University Global Capital Markets Center; Professor (Adjunct) of Business Administration, The Fuqua School of Business; and Special Counsel to the law firm of Kaye Scholer LLP. This article is based in part on The Universal Language of Cross-Border Finance, 8 DUKE J. COMP. \& INT'L L. 235 (1998). I wish also to thank my colleagues Willys H. Schneider, a partner, and Kathleen O'Keefe, an associate, at Kaye Scholer LLP for helping to write the tax discussion.

1. This raises a threshold question of the propriety of separating a company from its most liquid assets. According to legend, a lawyer, upon learning of securitization, uttered that "it is a perversion of natural law if the jewels of a company could be spirited away by lawyers' trickery." For a discussion of whether securitization ultimately provides benefits that outweigh any perceived detriments, see Steven L. Schwarcz, Structured Finance, A Guide to the PRINCIPLES OF ASSET SECURITIZATION A-1 (3d ed. 2002) (analyzing whether securitization is a zero-sum game).

2. The capital markets are "markets where capital funds—debt and equity-are traded. Included are private placement sources of debt and equity as well as organized markets and exchanges." JOHN DOWNES \& JORDAN GOODMAN, DICTIONARY OF FINANCE AND INVESTMENT TERMS 59 (5th ed. 1998). 
lower costs, while investors in the securitized assets benefit by holding investments with lower risk.

In contrast, a company traditionally raises money by issuing securities that represent equity in the company or, in the case of debt securities, entitle the holders to claims for repayment. Sometimes payment of those claims is secured by a lien on certain of the company's properties. In each case the security holder looks primarily to the company for repayment. If the company becomes financially troubled, or bankrupt, payment of the securities may be jeopardized, or at least delayed.

Securitization, however, can change the security holder's dependence on the company for payment, by separating the source of payment from the company itself. In a typical structured financing, a company that seeks to raise cash may transfer certain of its assets to a special purpose vehicle or trust (hereinafter SPV) that is organized in such a way that the likelihood of its bankruptcy is remote. ${ }^{3}$ The company involved is called the originator, because it usually originates the assets. The transfer is intended to separate the assets from risks associated with the originator. For this reason, the originator will often structure the transfer so that it constitutes a "true sale," ${ }^{4}$ a sale that is sufficient under bankruptcy law to remove the assets from the originator's bankruptcy estate.

To achieve bankruptcy remoteness, the SPV's organizational structure also strictly limits its permitted business activities. The goal is to prevent creditors (other than holders of the SPV's securities) from having claims against the SPV that would enable them to file an involuntary bankruptcy petition against the SPV. Furthermore, an SPV that is owned or controlled by the originator is usually required to have one or more independent directors. The SPV must also attempt to observe all appropriate third party formalities with the originator. These additional steps help to reduce the risk that the originator, if bankrupt, will either cause the SPV to voluntarily file for

3. See Steven L. Schwarcz, The Alchemy of Asset Securitization, 1 STAN. J.L. Bus. \& Fin. 133 (1994); 1 SECURITIZATION OF FinANCIAL Assets $§ 5.01$ (Jason H.P. Kravitt ed., 2d. ed. 1996 \& Supp. 2002)

4. 1 SeCuritization of FinAnCial AsSets, supra note $3, \S 5.03$. The term "true sale" sometimes creates confusion because the characterization of a given transfer as a sale could refer to the accounting, usury, tax, or bankruptcy treatment of the transfer, each of which is governed by different criteria.

5. 11 U.S.C. $\S 541$ (2000). Securitization is unlikely to create a fraudulent conveyance under Section 548 of the U.S. Bankruptcy Code (or equivalent state fraudulent transfer law), because the purchase price paid to the originator is normally a reasonable exchange for the receivables sold. 11 U.S.C. $§ 548$ (2000). 
bankruptcy or persuade a bankruptcy court, in the exercise of its equitable powers, to substantively consolidate the assets and liabilities of the SPV with those of the originator. ${ }^{6}$

The result is that the assets are no longer owned by the originator, but by the SPV. The assets themselves are typically payment obligations, such as accounts or other amounts receivable, owing to the originator from third parties. Those payment obligations generically are referred to as "receivables" or, sometimes, "financial assets.," The entities obligated to pay the receivables are known as "obligors."

The SPV, and not the originator, will issue securities-usually debt or debt-like instruments-to raise cash. ${ }^{8}$ Those securities are intended to be payable from collections on the receivables purchased by the SPV. A potential buyer of the securities therefore looks to the cash flow from the purchased receivables, and not necessarily to the credit of the originator, for repayment. The risk that these payments may not be made on time is an important factor in valuing the receivables. As long as the originator can reasonably predict the aggregate rate of default, however, it can securitize even those receivables that present some risk of uncollectibility. Therefore, a statistically large pool of receivables due from many obligors, for which payment is reasonably predictable, is generally preferable to a pool of a smaller number of receivables due from a few obligors.

The separation of the selling company from the receivables themselves can enable the originator to raise funds at less expense, through securities issued by the SPV, than if it raised funds through securities it issued directly. For example, the securities issued by the SPV, depending upon the structure of the transaction, may have a higher investment rating than securities issued directly by the originator and, therefore, would bear a lower interest rate than the originator might be able to obtain on its own securities, bank lines of credit, or secured borrowings. In addition, the cash that is raised usually will not require an offsetting liability to be shown on the originator's balance sheet; from the standpoint of the originator, the cash represents proceeds of the sale of receivables to the SPV.

6. For a discussion of substantive consolidation, see SCHWARCZ, supra note $1, \S 3: 4$, at 322-3-24 \& nn.135-38.

7. Receivables can be short term (typically due in thirty days), such as trade receivables, which represent the right to payment for goods sold or services rendered, or they can be long term, such as payments due over a period of years under loans, leases, licenses, management contracts, and other agreements.

8. These securities are sometimes referred to as "asset-backed securities." 
If the originator is a bank or similar financial institution that is required to maintain risk-based capital under the capital-adequacy guidelines, ${ }^{9}$ securitization could also permit the originator to sell receivables (e.g., loans reflected as assets on a bank's financial statements) for which it would otherwise be required to maintain capital. That reduces the bank's effective cost of funds.

Further, an originator may be restricted by its indenture covenants from incurring or securing debt beyond a specified level. A structured financing may enable the originator to raise cash in compliance with such covenants, because the originator may be selling receivables and not incurring or securing debt. (Whether a structured financing would violate particular covenants requires a case-by-case inquiry.)

\section{SECURITIZATION IN A CROSS-BORDER CONTEXT}

Securitization has an increasingly international focus, in part because companies that wish to raise funds from the capital markets may not be located in countries with established capital markets. ${ }^{10}$ In order to access capital market funding, those companies will have to structure deals that cross their national borders.

But cross-border securitization can be daunting to the uninitiated. It involves multiple legal systems with strange terms and sometimes even stranger rules. Even if one could master the complexities of a foreign legal system, one's mastery would inevitably be shortlived, for laws keep changing. It is, however, unnecessary for a lawyer who does not regularly practice in foreign jurisdictions to try to keep up with changes in foreign legal systems. ${ }^{11}$ All that is needed is a grasp of the fundamental legal principles of cross-border finance, in order to ask the right questions of local counsel and understand the response and its implications. ${ }^{12}$ It is, effectively, like learning a new language, but one that has remarkable similarities to our own legal language if one focuses on the fundamentals. ${ }^{13}$

9. See Capital Adequacy Guidelines for Bank Holding Companies and State Member Banks: Leverage Measure, 12 C.F.R. pt. 225, app. B (2002).

10. Established capital markets are located, for example, in New York, London, Hong Kong, and other major financial centers.

11. This clearly does not suggest that foreign lawyers should not keep up with their own jurisdictions' laws.

12. It is important that local counsel understands the implications of the question in order to think through any related legal principles.

13. In the following discussion, the perspective shifts back and forth among the originator, the SPV, and investors in securities issued by the SPV, because all these perspectives must be taken into account in structuring a securitization transaction. 
Recognizing that a growing segment of the world's money is now locked into receivables, ${ }^{14}$ and realizing the possibilities for economic growth by unleashing that wealth, the United Nations Commission on International Trade Law (UNCITRAL) has undertaken a project to simplify cross-border receivables financing and reduce its cost. ${ }^{15}$ To that end, UNCITRAL's work has focused on drafting the Convention on the Assignment of Receivables in International Trade (the Convention). ${ }^{16}$ The Convention applies only to the assignment of receivables, and specifically avoids involvement in any other part of the financing contract. ${ }^{17}$ However, its broad definition of "receivable" would make it applicable to securitization.

\section{A. Threshold Analysis: Jurisdictional Questions and the Source of the Financing}

The first step in any potential cross-border securitization is to determine its jurisdictional framework, including the jurisdictions of the company seeking financing - in our case, the originator-and of the source of that financing. A French company seeking to raise funds from French capital markets is not engaged in a cross-border financing; it is a French financing and French law applies. But if a French company wants to use securitization to obtain funding from U.S. (or London or Singapore) capital markets, it is a cross-border financingrequiring examination of the laws of the jurisdictions whose borders have been crossed and the manner in which those laws work (or, more often, fail to work) together. ${ }^{18}$

14. Spiros V. Bazinas, An International Legal Regime for Receivables Financing: UNCITRAL's Contribution, 8 DUKE J. COMP. \& INT'L L. 315 (1998); see also Summary of UNCITRAL's Work on Assignment in Receivables Financing (1997) (on file with the author) (noting that "in developed countries the bulk of corporate wealth is locked up in receivables").

15. UNCITRAL's Working Group on International Contract Practices (Working Group) first began work on receivables financing in 1995. See Bazinas, supra note 14, at 316.

16. United Nations Convention on the Assignment of Receivables in International Trade, opened for signature Dec. 12, 2001, G.A. Res, 56/81, U.N. GAOR, 56th Sess., U.N. Doc. A/RES/56/81 (2002), available at http://www.uncitral.org/stable/res5681-e.pdf (last visited Mar. 5, 2002); United Nations Convention on the Assignment of Receivables in International Trade, available at http://www.uncitral.org/english/texts/payments/ctc-assignment-convention-e.pdf (last visited Mar. 5, 2002) [hereinafter UNCITRAL Convention]. For a discussion of the status of the UNCITRAL Convention, see Spiros V. Bazinas, Multi-Jurisdictional Receivables Financing: UNCITRAL's Impact on Securitization and Cross-Border Perfection, 12 DUKE J. COMP. \& INT'L L. 365 (2002).

17. Bazinas, supra note 16 , at $365-7$.

18. The theme of knowing how to ask the right questions of local counsel presumes, of course, that there is a manageable number of jurisdictions in which local counsel will be needed. In some cases, many different jurisdictions have potential connections to the transaction. Re- 
Where capital markets are the source of financing, one also must consider the local regulatory restrictions on the use of those markets. For example, U.S. capital markets are a significant source of securitization financing because they have a broad investor base and efficient pricing. ${ }^{19}$ However, the issuance of securities to investors in these markets may require disclosure and regulation, particularly if the securities are issued without restrictions on trading (so-called "public" offerings). ${ }^{20}$ In contrast, offshore or Euromarkets may be more flexible, ${ }^{21}$ but may have a more limited investor base. Issuers of securities

solving those conflicts of laws, to try to reduce the number of local counsel, is the subject of a considerable literature which is beyond the scope of this article. See, e.g, John G. COLLIER, CONFLICT OF LAWS (1994); LAWRENCE COLLINS, ESSAYS IN INTERNATIONAL LITIGATION AND THE CONFlict OF LAWS (1994); DiCEY AND MORRIS ON THE CONFLICT OF LAWS (Lawrence Collins et al. eds., 1993); Friedrich K. Juenger, Choice of LAW AND Multistate Justice (1993); Eugene F. SCOles \& Peter Hay, Conflict of LaWs (2000).

19. Whether capital markets are efficient has been the subject of some debate. This debate revolves around the so-called "efficient market hypothesis." For a discussion of this debate, see JAMES D. Cox ET AL., SeCurities Regulation: CASES AND MATERiAls 31-43 (3d ed. 2001).

20. The United States has a complex regulatory framework for issuing and dealing with securities. See Schwarcz, supra note 1, at ch. 6. This framework is based on the Securities Act of 1933, 15 U.S.C. $\S 77$ (2000), and the Securities Exchange Act of 1934, 15 U.S.C. $§ 78$ (2000). For other countries see, for example, Giovanni Nardulli \& Antonio Segni, EU Cross-Border Securities Offerings: An Overview, 19 FORDHAM InT'L L.J. 887 (1996); Barry A.K. Rider, Global Trends in Securities Regulation: The Changing Legal Climate, 13 DICK. J. INT'L L. 513 (1995); Joel P. Trachtman, Unilateralism, Bilateralism, Regionalism, Multilateralism, and Functionalism: A Comparison with Reference to Securities Regulation, 4 TRANSNAT'L L. \& CONTEMP. PRoBs. 69 (1994); Manning G. Warren III, The European Union's Investment Services Directive, 15 U. PA. J. INT'L Bus. L. 181 (1994); Samuel Wolff, Recent Developments in International Securities Regulations, 23 DENV. J. INT’L L. \& POL'Y 347 (1995).

21. The prefix "Euro" indicates a type of transaction which is conducted offshore and involves lenders or borrowers from countries other than that of the currency of denomination. The markets are primarily the Eurobond, Eurocredit, and Eurodollar markets. Eurobonds are corporate bonds in U.S. dollars or other currencies, which are sold outside the country whose currency is used. See 1 The New PAlgrave Dictionary of Money \& Finance 783 (Peter Newman et al. eds., 1992). They "have become an important source of debt capital for both large and small companies throughout the world. Normally, a Eurobond issue is syndicated by a consortium of international investment banks. This provides wide exposure to investors in different countries." The Portable MBA Desk RefEREnCE: AN ESSENTIAL Business COMPANION 174 (Paul A. Argenti ed., 1994). Eurocredit is a loan offered simultaneously from several banks from more than one country. See 1 THE New PALgRAVE Dictionary of MONEY \& FINANCE, supra, at 783. Eurodollars, a subset of Eurocurrency, means U.S. currency held in a deposit outside the United States, primarily Europe. Sometimes securities, debt as well as equity, will be denominated in Eurodollars, which will have the effect of principal, interest, and dividends being paid out of U.S. dollars deposited outside the United States. Whether this is attractive or not is influenced by exchange rates, but U.S. companies tend to

raise capital in European [or other overseas] markets when U.S. market rates are unfavorable. This action can be an especially attractive avenue for companies making an initial public offering that splits into two tranches-one to be traded on U.S. exchanges, and the other, a Eurotranche, to be traded on a European exchange.

The Portable MBA Desk Reference: An EsSENTIAL Business COMPANiOn, supra, at 175. 
sometimes can avoid regulation entirely by combining markets-for example, using U.S. capital markets for a private placement of subordinated debt to support a public offering of senior debt securities conducted offshore.

\section{B. Structuring the Transaction}

As discussed in Part I, investors generally prefer that the transfer of receivables from the originator to the SPV be structured as a sale. ${ }^{22}$ This is especially true where local law would protect the originator's assets against creditor enforcement, as with the automatic stay under U.S. bankruptcy law. ${ }^{23}$ In a cross-border context, however, the parties can reduce costs by structuring the transfer of receivables as a secured loan, rather than a sale ${ }^{24}$ if the SPV (as creditor) would be able to enforce its rights against the pledged receivables in the event of the local law equivalent of a bankruptcy case against the originator. ${ }^{25}$

A related question is how the originator must account for the transaction on its balance sheet. If the transaction is a loan, the originator would account for it as debt. But if the transaction is accomplished through a sale, the originator may be able to avoid booking a debt ("off-balance sheet financing"). ${ }^{26}$ The ultimate accounting treatment would be subject to the accounting principles that prevail in the originator's jurisdiction, ${ }^{27}$ although there is some movement towards international harmonization of accounting standards. ${ }^{28}$

22. See supra note 4 and accompanying text (discussing the importance of structuring a securitization transaction as a true sale under U.S. law).

23. See 11 U.S.C. $\$ 362$ (2000). A secured creditor could not foreclose on its collateral without court permission, which is rarely given. European countries increasingly have been adopting bankruptcy laws that include a stay of action by creditors against a bankrupt company in order to facilitate the company's rehabilitation. See generally Eberhard Schollmeyer, The New European Convention on International Insolvency, 13 BANKR. DEV. J. 421 (1997).

24. The parties can thereby save the significant transaction costs of implementing a "twotier" sale structure, which is often necessary in a sale context to enable the originator to recoup the residual value of the transferred receivables once the SPV's investors are paid in full. See Schwarcz, supra note 3, at 141-42.

25. For an article analyzing whether particular securitization transactions should be viewed as loans or sales, see Peter Pantaleo et al., Rethinking the Role of Recourse in the Sale of Financial Assets, 52 Bus. LAw. 159 (1996).

26. See Schwarcz, supra note 3, at 142.

27. Accounting principles vary widely among countries. In the United States, Generally Accepted Accounting Principles (GAAP) are used for reporting purposes. For other purposes, as in tax or corporate law, deviations from GAAP are used. How substantial the differences between jurisdictions can be is best illustrated by an example. When Daimler-Benz, the German automaker, wanted to have a listing on the New York Stock Exchange, it did not want to file financial information according to U.S. GAAP. When it eventually did file, it showed a loss of DM 949 million instead of a profit of DM 168 million it had shown under German accounting 


\section{Commercial Finance Issues}

I next examine how the SPV and its investors stand as against the originator's creditors, and whether any part of the securitization transaction is potentially preferential, fraudulent (whether intentionally or, under local law, constructively), or in some other way problematic. These questions typically are addressed by laws that seek to allocate priority to collateral or to ensure equality of distribution, or preserve the integrity, of a debtor's estate.

1. Perfection and Priority. The term "perfection" often is used to refer to protection of a transferee's interest in transferred assets from creditors of the transferor. ${ }^{29}$ For assets that are physically located in a particular jurisdiction, the law of that jurisdiction, or sometimes of the transferor's jurisdiction, usually governs perfection. In a securitization transaction, perfection means protecting the SPV's interest in the transferred receivables from claims of the originator's creditors. Because receivables are intangible and therefore not physically located in any particular jurisdiction, the law of the originator's jurisdiction intuitively would be expected to, and usually does, govern perfection. $^{30}$

Some jurisdictions have a filing or other public notice system for perfection. $^{31}$ Other legal systems may require notification of obligors, which may be unacceptable and expensive. ${ }^{32}$ Often, the local perfec-

rules. See David Waller, Daimler-Benz Pierces Accounting Mystique, FIn. TIMES, Sept. 23, 1993, at 24; see also Richard Waters, Survey of Accessing the U.S. Capital Markets (2): The World According to U.S. GAAP, FIN. TIMES, Feb. 1, 1996, at 34.

28. See Peter C. Jeffrey, International Harmonization of Accounting Standards, and the Question of Off-Balance Sheet Treatment, 12 DUKE J. COMP. \& INT'L L. 341 (2002).

29. Or from the transferor's bankruptcy representative. In some jurisdictions, the concept of perfection is not well recognized. Once an asset is transferred, the transferor is simply deemed no longer to have an interest in the asset.

30. Under the UNCITRAL Convention, the location of assignor would govern. See Bazinas, supra note 16, at 381; accord U.C.C. § 9-103(3) (2000). This is not, however, a universal rule. Some jurisdictions may look, for example, to the "law of the receivable," meaning the law of the contract under which the receivable arose or the law of the jurisdiction where the obligor is located. Except to the extent large concentrations of obligors are located in a given jurisdiction, it may be impractical to consult local counsel in each obligor's jurisdiction.

31. The purpose of filing is "to place third parties on notice of the transfer" of the asset. In the United States, this is usually done by filing a U.C.C.-1 financing statement. UNCITRAL has proposed a registration system for this purpose. See SCHWARCZ, supra note 1, at B-1 (International Perfection).

32. Besides the obvious costs involved in having to notify all the obligors of, for example, trade receivables, it sometimes may also be culturally unacceptable to do so because notification might be seen as a signal that the company is in financial difficulties. "This is a problem practitioners often run into ... But it is a problem that is not documented in the literature." Petrina 
tion procedures may be unclear or impractical, in which case investors are forced to rely on the originator's representations, warranties, and covenants that the receivables transferred to the SPV are, and will remain, unencumbered by third parties. ${ }^{33}$

Priority generally refers to the ranking of multiple claims against a transferred asset. In a securitization context, it means that the SPV's and investors' claims against the transferred receivables are superior to any third-party claims. ${ }^{34}$ Priority is normally accomplished, in a jurisdiction that perfects by filing, by being the first to file against the receivables. ${ }^{35}$ If the originator is located in a jurisdiction that does not have a filing or other registration system to indicate priority, the investors again may have to rely on the originator's representations, warranties, and covenants. This, of course, creates a much greater risk of fraud than where a public filing system is used.

If the transaction involves receivables that will be created at a future date ${ }^{36}$ one also must ask if the local law permits the transfer of an asset not then in existence. ${ }^{37}$ Bankruptcy or insolvency laws ${ }^{38}$ also may restrict an originator's ability to transfer its future receivables. ${ }^{39}$

R. Dawson, Rating Games with Contingent Transfer: A Structured Finance Illusion, 8 DUKE J. COMP. \& INT'L L. 381, 399 n.102 (1998).

33. However, see SCHWARCZ, supra note 1, at B-7-B-11 (analyzing the potential benefits of implementing a uniform perfection system for securitization and other forms of cross-border receivables financing).

34. Priority refers generally to the "relative ranking of claims to the same property .... In bankruptcy, [it] refers to secured claims that by statute receive more favorable treatment than other, unsecured, claims.” BLACK's LAW DICTIONARY 1212 (7th ed. 1999).

35. Sometimes referred to as "first-in-time, first-in-right," this generally gives priority to the first person to file against the asset. Priority is ascertained by searching the filing records to determine whether other parties have prior filings against the relevant assets. See, e.g., U.C.C. $\S$ 9-322 (2000).

36. For example, certain cross-border financings are supported by payments to be made in the future under international telephone contracts. An example for such a transaction is the private placement by Teléfonos de México, S.A. (TelMex), the Mexican telephone company. For further information on this transaction, see generally Claire A. Hill, Latin American Securitization: The Case of the Disappearing Political Risk, 38 VA. INT’L L.J. 293 (1998).

37. The UNCITRAL Convention allows for this. See Bazinas, supra note 16, at 372; see also Steven L. Schwarcz, The Parts Are Greater Than the Whole: How Securitization of Divisible Interests Can Revolutionize Structured Finance and Open the Capital Markets to Middle-Market Companies, 1993 Colum. Bus. L. REV. 139, 149 n.36 (examining U.S. law on selling future payments under a contract not yet in existence). Many civil laws provide that a pledge or assignment can only be made when an asset exists. This is based on the civil law view that a pledge is a real right "as opposed to a personal right; it gives the creditor a right to seize and sell assets and get a privilege on the proceeds of the sale." Michael H. Rubin \& McGinchey Stafford Lang, Recent Developments In Security Devices, With an Emphasis on Louisiana Law, ALIABA COURSE OF STUDY 571, 588, Westlaw, ALI-ABA file. 
Without a system for making transfers of receivables publicly ascertainable, securitization is discouraged because the SPV will not be able to determine its priority at the time of the transfer. UNCITRAL's Convention proposes an optional centralized registration system that could be used to provide such notice. It would provide, for states opting in, that "[a]s between assignees of the same receivable from the same assignor, the priority of the right of an assignee in the assigned receivable is determined by the order in which data about the assignment are registered [under a centralized registration system established by the Convention], regardless of the time of transfer of the receivable." ${ }^{40}$

2. Commingling. Another risk is that cash proceeds of receivables pledged or sold to an SPV may be mixed, or "commingled," with the originator's own funds. This risk to some extent reflects common sense: if the originator is freely permitted to use collections, a court may find the originator's control inconsistent with the SPV's claim that it has a perfected interest in the collections. Local law may ameliorate this risk somewhat. ${ }^{41}$ Commingling also can be prevented by using lockboxes, or by segregating cash flows. Control over cash flows - such as requiring obligors to make payments into a trust account located in the U.S.-also may mitigate the perfection risk. ${ }^{42}$ If these approaches are not available, one should ascertain whether pro-

38. Such as 11 U.S.C. $§ 552$ (2000). See Steven L. Schwarcz, Protecting Rights, Preventing Windfalls: A Model for Harmonizing State and Federal Laws on Floating Liens, 75 N.C. L. ReV. 403, 434 (1997) (analyzing U.S. bankruptcy law restrictions on floating liens, and arguing those restrictions should not apply to securitization transactions).

39. In a collateral context, a lien on future arising assets is often referred to as a floating lien. See U.C.C. § 9-204 cmt. 2 (2000).

40. Annex to the UNCITRAL Convention, supra note 16, § I, art. 1; see also UNCITRAL Convention, supra note 16, art. 42 (implementing optional registration). This rule contrasts, for example, with a rule that would determine priority by the time of transfer of the receivables, which is not always ascertainable. For an expanded discussion of these issues, see SCHWARCZ, supra note 1 , at B-3-B-4.

41. See, e.g., U.C.C. $\$ 9-315$ (2000) (allowing tracing of proceeds).

42. In civil law countries, however, bailment, custody, and other trust concepts may not always be recognized with respect to commingled cash, as civil law countries generally do not recognize trust concepts. See generally Justin P. Thorens, The Common Law Trust and the Civil Law Lawyer, in COMPARATIVE AND PRIVATE INTERNATIONAL LAW: ESSAYS IN HONOR OF JOHN HENRY MERRYMAN ON HIS 70TH BIRTHDAY 309-15 (David S. Clark ed., 1990); Donovan W.M. Waters, The Institution of the Trust in Civil and Common Law, 252 RECUEIL DES Cours 113 (1995). But see Maurizio Lupoi, The Civil Law Trust, 32 VAND. J. TransnAT'L L. 967, 968-69, 976-79 (1999) (arguing that the trust is a civil law concept). 
ceeds are traceable, and ask local counsel whether traced proceeds are protected. $^{43}$

Under the Convention, commingling risk is minimized. ${ }^{44}$

3. Preferential and Fraudulent Transfers. The bankruptcy, insolvency, or related laws of some jurisdictions may permit or require a bankrupt company (or its representative) ) $^{45}$ to avoid transfers of assets, or obligations incurred, by the company prior to its bankruptcy. Some of these laws-referred to as preference laws because they avoid preferential transfers-are intended to ensure equality of distribution of the company's assets among all its creditors. ${ }^{46}$ Less frequently, transfers made or obligations incurred by a troubled company for less than equivalent value may be deemed to be fraudulent and therefore voidable. ${ }^{47}$

In a securitization context, preference and fraudulent transfer laws are unlikely to apply because any transfers of receivables from the originator to an SPV tend to be structured as sales for arm's length consideration.

43. Another potential concern is that the method of perfection may refer to the original collateral, but not to the proceeds. If the anticipated form of the proceeds is known (e.g., cash), that concern can be alleviated by also describing the proceeds.

44. Article 14.1(b) of the Convention provides that "[i]f payment in respect of the assigned receivable is made to the assignor, the assignee is entitled to payment of the proceeds." UNCITRAL Convention, supra note 16, art. 14.1(b). Article 24.2 of the Convention provides that "[i]f proceeds are received by the assignor, the right of the assignee in those proceeds has priority over the right of a competing claimant in those proceeds ... if (a) The assignor has received the proceeds under instructions from the assignee to hold the proceeds for the benefit of the assignee; and (b) The proceeds are held by the assignor for the benefit of the assignee separately and are reasonably identifiable from the assets of the assignor, such as in the case of a separate deposit or securities account containing only proceeds consisting of cash securities." Id. art. 24.2(a), (b). Article 13.1 also would lessen the likelihood that commingling would occur, by authorizing the assignor or assignee to notify the obligor on the receivables to pay the assignee directly: "[T] he assignor or the assignee or both may send the debtor [i.e., the obligor on the receivables] notification of the assignment and a payment instruction, but after notification has been sent only the assignee may send such an instruction." Id. art. 13.1. Article 17.2 clarifies that "[a]fter the debtor [i.e., the obligor on the receivables] receives notification of the assignment, ... the debtor is discharged only by paying the assignee ... or in accordance with such payment instruction." Id. art. 17.2.

45. Under U.S. bankruptcy law, that representative is called the trustee in bankruptcy. 11 U.S.C. $\$ 704$ (2000).

46. In the United States, for example, 11 U.S.C. $§ 547$ (2000) limits preferential transfers made within ninety days (or, if the transferee is an "insider," made within one year) of the company's bankruptcy.

47. Whether or not the transfer in fact is fraudulent. The concept of "constructive fraud," for example, is codified at 11 U.S.C. $§ 548(a)(1)(B)(2000)$. 
The Convention does not cover these issues directly, but it does generally specify the choice of preference law that would apply. ${ }^{48}$ This may allow the parties to a receivables financing to better understand their rights by consulting insolvency counsel who are expert in that law.

\section{Contractual and Legal Restrictions}

The next issue is whether contractual or legal restrictions affect the financing. There are two ways that contractual restrictions can arise. First, there may be restrictions (anti-assignment clauses) in the contract pursuant to which collateral or receivables are originated. For example, a lease or license contract may prohibit the lessor's (or licensor's) assignment of rights to payment received thereunder. Under U.S. law, certain restrictions on the assignment of receivables, such as accounts receivable, are unenforceable, but the laws of other jurisdictions will differ. ${ }^{49}$

The Convention permits certain assignments notwithstanding anti-assignment clauses. ${ }^{50}$ However, the Convention still protects obligors who would be harmed by the assignment by making the assignor liable for breach of the prohibition. ${ }^{51}$ The Convention also protects obligors by clarifying that the assignment of receivables does not increase their burden. ${ }^{52}$

Contractual restrictions also can arise through negative pledge or similar covenants contained in the originator's financing documents. ${ }^{53}$

48. UNCITRAL Convention, supra note 16, arts. 22, 23.3, 30.3 .

49. See U.C.C. § 9-406 (2000); Bazinas, supra note 16, at 372 . The implicit rationale for nullifying restrictions on the assignment of receivables might be that the obligor on the receivable is not prejudiced by its assignment, whereas enforcing an anti-assignment clause would impair the free alienability of property rights. A receivable represents the originator's right to payment; and property, after all, is merely a bundle of rights.

50. Article 9.1 of the Convention provides that "[an] assignment of a receivable is effective notwithstanding any agreement between the ... assignor and the debtor [i.e., the obligor on receivables] . . limiting in any way the assignor's right to assign its receivables." UNCITRAL Convention, supra note 16, art. 9.1. Article 9, however, only applies to the types of receivables listed in subsection (3) thereof. Id. art. 9.3.

51. Article 9.2 of the Convention provides that "[n]othing in this article affects any obligation or liability of the assignor for breach of such an agreement." Id. art. 9.2. The assignee, however, is not necessarily liable to the debtor for such a breach: "A person who is not party to such an agreement is not liable on the sole ground that it had knowledge of the agreement." Id.

52. Thus, Article 15.1 of the Convention provides that "assignment does not, without the consent of the debtor [i.e., the obligor on the receivables], affect the rights and obligations of the debtor, including the payment terms contained in the original contract." Id. art. 15.1.

53. These financing documents typically were put into place for other financings, not the financing being structured. For example, negative pledge clauses prohibit or limit the creation 
Sometimes financings must be restructured to get around a restrictive covenant. $^{54}$ This takes creativity and an understanding of how the covenant is to be interpreted. For example, would a covenant restricting a secured loan also restrict a sale? The answer can be ambiguous if, under the governing law, the line between a sale and a secured loan is unclear. Furthermore, the governing law is not always obvious. For example, the covenant may be contained in a financing document stated to be governed by English law, but the covenant may prohibit liens on assets of a company located in Mexico. To determine whether English law or Mexican law governs the interpretation of whether the financing in question violates the covenant by creating a lien, counsel in both jurisdictions must be consulted. Sometimes even then the answer may be unclear.

Finally, one must consider whether local law itself restricts the financing.

\section{E. Enforcement Issues}

In an international context, it is not enough to have theoretical rights under the law. The critical question is whether one can enforce those rights, ${ }^{55}$ recognizing that the legal system granting the rights may not be the same as the one in which enforcement occurs, and that foreigners may not be viewed favorably when enforcing rights against local citizens. Investors will want the originator to submit to their jurisdiction, or at least the jurisdiction of the SPV. ${ }^{56}$ Of course, investors must determine whether those jurisdictions would enforce such an arrangement. Submission to jurisdiction could entail, for example,

of secured debt. On the issue of negative pledge clauses, see generally Thomas C. Mitchell, The Negative Pledge Clause and the Classification of Financing Devices: A Question of Perspective, First Installment, 60 AM. BANKR. L.J. 153 (1986); Thomas C. Mitchell, The Negative Pledge Clause and the Classification of Financing Devices: A Question of Perspective, Second Installment, 60 AM. BANKR. L.J. 263 (1986).

54. Sometimes the covenants are so restrictive that the securitization simply cannot be accomplished.

55. A scene from a Broadway play about a "realpolitik" elementary school class illustrates this general point. In the math lesson, the teacher asked how Joe, Jim and Bob would split six bananas if Joe had two, Jim had four, and Bob joined them for lunch. The answer was that Bob was strongest and took all the bananas.

56. To be able to adjudicate a case, a court must have both subject matter and personal jurisdiction. See Black's LAw Dictionary, supra note 34, at 852. Subject matter jurisdiction means a court can hear a particular kind of case. See id. at 852, 1438. Personal jurisdiction means the court has legal power over the parties to enforce a judgment. See id. at 857 . While several legal grounds exist for personal jurisdiction, from the perspective of a potential plaintiff the "safest" way to ensure such jurisdiction is to obtain consent of the party before a cause of action has arisen. 
appointing an agent of the originator in the investors' (or SPV's) jurisdiction to accept service of legal process, usually referred to as a "process agent."

If investors can obtain jurisdiction over the originator in their own (or the SPV's) jurisdiction, it may not matter that the originator has no significant assets outside of its home jurisdiction. Investors would simply sue where the originator has submitted to jurisdiction, obtain a judgment, and take the judgment to the originator's home jurisdiction to be enforced. ${ }^{57}$ However, counsel in the home jurisdiction should be consulted in advance to verify whether such a judgment would be recognized and what, if any, defenses could be raised to its enforcement.

Another potential problem is that the originator itself could be immune from suit under its local law, particularly if it has sovereign or quasi-sovereign ownership. ${ }^{58}$ Requiring the originator to waive sovereign immunity may be a solution to this problem. In the U.S., for example, such a waiver is enforceable under the U.S. Foreign Sovereign Immunities Act of 1976, as amended. ${ }^{59}$ This, however, only means that U.S. courts will respect the waiver of sovereign immunity. One still must ask local counsel whether the waiver will be respected in the originator's jurisdiction.

Other sovereign risks include currency exchange controls-the risk that the originator's home jurisdiction may limit the export or private use of U.S. dollars or other relevant foreign currency. ${ }^{60}$ This

57. While arbitral awards are governed by the U.N. Convention for the Recognition and Enforcement of Foreign Arbitral Awards, no such treaty exists for the enforcement of foreign judgments. Countries often recognize foreign judgments on the basis of reciprocity. In the United States, this varies from state to state; however, several states have adopted the Uniform Foreign Money Recognition Act and the Uniform Enforcement of Foreign Judgment Act. See generally Shirley Sostre-Oquendo, Recognition and Enforcement of Foreign Judgments in the United States and Canada in the Free Trade Era, 1992 DET. C. L. REV. 1019; see also Christopher P. Hall \& David B. Gordon, Enforcement of Foreign Judgments in the United States 57 (1997), WESTLAW, INLPRAC file. In other countries, similar laws exist. See, e.g., InTRODUCTION TO THE LAW AND LEGAL SYSTEM OF KOREA 1152 (Sang Hyun Song ed., 1983).

58. Sovereign immunity is traditionally a concept of public international law. Under this concept the sovereign, historically the monarch, today the state and its officials, cannot be sued unless they consent. While it was considered to be absolute in the beginning, over time certain recognized exemptions have developed. See Malcom N. Shaw, InTERnational LaW 491522 (4th ed. 1997). The most important exemption under the U.S. Foreign Sovereign Immunity Act is the "commercial activity exemption." See 28 U.S.C. § 1603(d) (1994). A similar example can be found in the United Kingdom in § 3(3) of its State Immunity Act of 1978. See SHAw, supra, at 505 .

59. See 28 U.S.C. $§ \S 1330,1602-11$ (1994 \& Supp. 1999).

60. Currency control has occurred before in at least several places, for example in Brazil, Nigeria, China, Romania, South Africa, Venezuela and, at least de facto, in Mexico. See, e.g., 
risk might be mitigated by issuing securities denominated in local currency (rather than U.S. dollars). ${ }^{61}$ Risk mitigation can also be attained if the originator has significant assets outside its home jurisdiction or offshore obligors on receivables, ${ }^{62}$ or by arranging local currency swaps for U.S. dollars (discussed below). One should also inquire whether the originator's home jurisdiction has ever imposed, or is likely to impose, debt moratoria of the type that would restrict the originator from paying its debts to foreigners. ${ }^{63}$ Finally, inquiry should be made as to whether the SPV must be licensed in that jurisdiction to enforce its rights against the originator.

\section{F. Currency Exchange, Swaps, and Hedging}

Currency exchange issues loom large in cross-border finance. The problem is that the currency in which investors invest may be different than the currency received to repay them. For example, if investors buy U.S. dollar-denominated securities to enable an SPV to purchase a portfolio of Japanese yen-denominated receivables, the investors would be taking the added risk that, when the receivables pay, the dollar-to-yen exchange rate would yield insufficient dollars to

Scott McMurray, Soybean Futures Prices are Expected to Plunge on Reforms Unveiled by the President of Brazil, WALL ST. J., Mar. 19, 1990, at C12; Thomas Petzinger Jr. \& Peter Truell, U.K. Audit Points to Larger BCCI Role by Two Top U.S. Cable-TV Executives, WALl ST. J., Jan. 17, 1992, at A4; Trade Conference in Beijing Attracts U.S. Businessmen, WALL ST. J., June 21, 1988, at A65; Romania Revives Currency Curb, WALL ST. J., Feb. 27, 1992, at A8; Ken Wells, U.S. Investment in South Africa Quickens, WALL ST. J., Oct. 6, 1994, at A15; Observer: Caracas Chestnut, Fin. Times, July 25, 1994, at 15; David Asman, The Americas: Complex Models Won't Stop Mexico's Peso From Tumbling, WALl ST. J., Feb. 17, 1995, at A11. For a description of the international obligations that impact a country's ability to impose exchange controls, see generally Central and East European Law Initiative, Currency Exchange Controls: A Concept Paper Prepared for the Government of Bulgaria, 29 INT'L LAW. 257 (1995).

61. However, exchange controls could limit the export of the local currency. Furthermore, investors may not want to invest in securities denominated in a local currency.

62. That way, enforcement against those assets or obligors will not, de facto, be subject to the local laws of the company's country.

63. Debt moratoria have happened before, for example in the Philippines, South Africa, and Russia. See Julia Leung, Filipinos Plan Again to Issue Overseas Bonds, Wall St. J., Oct. 30, 1992, at B4; Neil Behrmann, South Africa Hopes to Reschedule Debt as Total Declines, Wall St. J., June 11, 1993; Terence Roth \& Tim Carrington, Moscow Stops Paying Bank Debt Principal, WALl ST. J., Dec. 5, 1991, at A3. Most recently, Indonesia was considering such a moratorium, but eventually opted against it. See Darren McDermott, Jakarta's Debt Plan Opens to Mixed Reviews, WALL ST. J., Feb. 3, 1998, at A1. Certain countries may have political risks. Political risk insurance sometimes may be available to cover specific risks, although it is very expensive. See Claire A. Hill, How Investors React to Political Risk, 8 DUKE J. COMP. \& INT'L L. 283 (1998). 
repay them. ${ }^{64}$ Investors generally prefer the exchange rate risk to be "hedged" through "swaps" and other derivative products.

A "derivative" product means a contract that creates future rights and obligations regarding an asset that underlies a larger transaction. $^{66}$ Derivative products can be broken down into forward contracts and options. In an option, one party pays for the right (but not the obligation) to buy an asset at a future date for a negotiated price. ${ }^{67}$ A forward contract is a contractual obligation to buy (or, from the seller's standpoint, to sell) an asset, such as foreign currency, at a specified price at a future settlement date. A swap is an array of forward contracts - a forward contract covering each date that settlement is to be made. ${ }^{68}$

Currency hedging is accomplished by entering into a swap with a third party (called a swap counterparty) to exchange the relevant currencies at the future settlement dates. ${ }^{69}$ The parties contractually agree in advance to the exchange rate that will be deemed to apply on

64. Of course, investors could convert the yen to dollars on the spot market. "A spot transaction involves the immediate purchase of, payment for, and delivery of a fixed amount of a currency. Such transactions are said to occur on the spot market." John Huguet, Global Financial Thinking, in AMA MANAGEMENT HANDBOOK 6-40, 6-43 (John J. Hampton ed., 3d ed. 1994). But fluctuating exchange rates put investors at risk that a weakened yen would yield insufficient dollars.

65. "Hedging, using the futures market, is the process of neutralizing or significantly reducing financial risks .... There are two fundamental reasons for hedging. The first is to reduce risk ... . The second is the ability to separate the timing decision from market opportunities." See Robert W. Hiller, Sources of Financing: Traditional and New, in AMA MANAGEMENT HANDBOOK 6-25, 6-32 (John J. Hampton ed., 3d ed. 1994).

66. See, e.g., Joseph L. Motes III, Note, A Primer on the Trade and Regulation of Derivative Instruments, 49 SMU L. REV. 579, 583-84 (1996). A great deal of derivative documentation is standardized worldwide through use of so-called "ISDA forms" developed by the International Swaps and Derivatives Association. See generally http://www.isda.org (last visited Apr. 28, 2002).

67. See Motes, supra note 66, at 589; Hiller, supra note 65, at 6-32.

68. See Motes, supra note 66, at 590. The actual underlying swapped assets are rarely exchanged. Rather, one party to the swap makes a payment to the other based on the net valuation of the swapped assets on the future settlement date. See JoHn F. MARShall \& Kenneth R. KAPNER, THE SWAPS MARKET 32 (2d ed. 1993) ("The underlying assets may or may not be exchanged and are referred to as notionals."). The asset could be foreign currencies in the case of currency swaps in cross-border finance transactions, or might be oil in the case of a swap involving a company that needs oil at a future date and wants to fix the price. Swaps are therefore akin to gambles on future asset values. Indeed, there is ongoing controversy as to whether derivative products can be abused, particularly where investors borrow on leverage to purchase derivative products for speculation. In a non-leveraged context, however, the use of derivatives to hedge currency (or interest rate) risks in cross-border transactions is not only prudent but essential for minimizing the risk to investors.

69. Counterparties are often financial institutions, or their affiliates, that deal in derivative products (swap dealers). 
those settlement dates to ensure that the currency conversion will yield sufficient dollars to repay investors. Thus, if the investors expect to receive payment in Japanese yen and, based on the anticipated amount of yen, need an exchange rate of 126.29 yen per U.S. dollar to be fully repaid in dollars, a swap counterparty would be sought who is willing to exchange dollars for yen at that rate on the future settlement dates. If on a settlement date the exchange rate has changed to 130 yen per dollar, the investors would be protected because the swap counterparty has taken the currency exchange risk. But the swap party would profit on the exchange if the exchange rate has become 125 yen per dollar.

Investors, of course, will want to be comfortable that the counterparty will be able to perform its swap obligations on each settlement date if the net value of the swap at that date runs against the counterparty. ${ }^{70}$ If, therefore, there is a realistic risk that the counterparty may be unable to perform, the investors may attempt to minimize performance risk by requiring the counterparty to collateralize its future obligations or obtain a third-party guaranty, not unlike a lender requiring assurance of future performance from a borrower. The performance risk also can be minimized by requiring the counterparty to make daily or other periodic adjustment payments of the changing net value of the swap, thereby reducing the risk that the counterparty will be unable to pay the net amount due at a future date. This is referred to as "marking to market."

The terms of the swap agreement also may be relevant. For example, any conditions precedent to effectiveness may need to be satisfied at the closing when the investors provide financing. Also, the SPV may be subject to taxes if it gains the advantage of the swap. ${ }^{72}$

\section{G. Tax Issues}

In general, there are three central tax issues that arise in securitization transactions. The first is whether the transfer of receivables

70. That is, if the exchange rate has changed to make the value of the currency that the counterparty has agreed to sell higher than the price it agreed to accept for the sale.

71. For a description of the mark-to-market methodology, see Jon Moynihan, Measuring the Risk Adjusted Profitability of Derivative Products on Bank Capital, in THE HANDBOOK OF CURRENCY AND INTEREST RATE RISK MANAGEMENT 25-1, 25-9-25-11 (Robert J. Schwartz \& Clifford W. Smith Jr. eds., 1990). Forward contracts that include periodic marking to market are called "futures contracts." For the relation between mark-to-market and futures, see MARSHALL \& KAPNER, supra note 68, at 19.

72. Investors may try to require payments to be made net of taxes. See infra Section II.G. (discussing indemnity and gross-up provisions). 
from the originator to the SPV will be treated for tax purposes as a sale, requiring recognition of gain or loss, or as a loan. The second is the degree to which the SPV itself will be subject to tax (the so-called "entity-level" tax). The third is the tax treatment of investors who purchase these securities.

From a U.S. standpoint, tax issues in cross-border securitization transactions include those relevant in purely domestic securitization transactions $^{73}$ as well as additional issues that may have to be determined under foreign as well as (or instead of) U.S. law, depending on the location of the originator, the receivables, and the SPV. These additional tax issues are discussed below.

1. Withholding Tax. Payments in a securitization transaction of amounts treated as interest for income tax purposes may be subject to U.S. or foreign withholding taxes, and the cost thereof must be factored into the particular transaction. This can occur, for example, if there is a tax sale of receivables with obligors in one country paying interest on the underlying receivables to an SPV or investors in another country; if a transaction between the originator in one country and an SPV or ultimate investor in another country is treated as a tax loan; or if an SPV in one country raises money by issuing debt to investors in another country.

Many countries, including the United States (at a statutory rate of thirty percent), impose a withholding tax on the gross amount of interest paid to certain foreign persons not otherwise engaged in business in the country from which the interest is paid. ${ }^{74}$ The amount is withheld by the payor on behalf of the payee and paid over to the appropriate taxing authority. ${ }^{75}$ Frequently, this withholding tax is re-

73. For a detailed discussion of these domestic issues, see SCHWARCZ, supra note 1, at ch. 5 .

74. 26 U.S.C. $\S \S 1441,1442$ (1994). There is a statutory exemption from U.S. withholding tax for "portfolio interest." 26 U.S.C. $\S \S 871($ h), 881(c) (1994 \& Supp. 1999). "Portfolio interest" does not, however, include interest received by a bank on an extension of credit made pursuant to a loan agreement entered into in the ordinary course of its trade or business (26 U.S.C. $\S 881(\mathrm{c})(3)(\mathrm{A})(1994))$, interest received by parties owning ten percent or more of the interests in a debtor corporation or partnership (26 U.S.C. $\$ \S 871(\mathrm{~h})(3)(B), 881(\mathrm{c})(3)(B)(1994))$, or certain "contingent" interest, determined by reference to cash flow, income, change in value of property or distributions made by a debtor or related person (26 U.S.C. $\S 871(\mathrm{~h})(4)$ (1994 \& Supp. 1999)). The portfolio interest exemption will be available in certain securitization transactions.

75. The IRS has issued new regulations which, to some degree, simplify the responsibilities of withholding agents and the means of identifying entitlement to exemptions from withholding tax. See, e.g., Treas. Reg. § 1.1441-1(e) (1997) (discussing withholding agent's reliance on beneficial owner withholding certificates, intermediary withholding certificates, qualified intermedi- 
duced or eliminated pursuant to the applicable terms of an income tax treaty between the country of the payee and that of the payor, but this will not always be the case. If not eliminated, it will be necessary to determine which party will bear the cost of the tax. In most cases, this cost will be borne by the payor, by means of an indemnity and "gross-up" provision under which the payor is required to pay the payee an extra amount so as to compensate, on an after-tax basis, for the tax withheld. Establishing an SPV in a tax haven jurisdiction or in a jurisdiction with a wide tax treaty network sometimes may minimize withholding tax costs.

Bilateral tax treaties (between the originator's and the SPV's jurisdictions), where they exist, can reduce or eliminate withholding taxes. For example, such tax treaties exist between the United States and most major European countries, and also among European Union countries.

2. Taxation of the SPV and Its Shareholders. As noted above, it sometimes may be desirable to form an SPV involved in a crossborder securitization in a tax haven jurisdiction. This will both minimize withholding tax on any interest payments made by the SPV and avoid mainstream tax on net income of the SPV, assuming it is an entity subject to such tax. Use of a tax haven can, however, also increase the potential withholding tax burden on any interest payments to be made to the SPV, either by the underlying obligors on the receivables or by the originator, because tax havens are not typically parties to tax treaties that would eliminate withholding taxes.

It is also important to ensure that the SPV will not be subject to any mainstream income tax in a jurisdiction other than that in which it is actually resident. For example, if the SPV owns receivables of obligors in another jurisdiction and the originator services the receivables in that other jurisdiction on behalf of the SPV, the question arises whether the SPV will be deemed to be "doing business" or to have a "permanent establishment" in that jurisdiction. Either finding could subject the SPV to mainstream income tax in that jurisdiction. Generally, however, the SPV will not be subjected to such tax if the servicer is performing purely ministerial functions and has no power to bind the SPV in any way (e.g., by virtue of being able to agree to changes in the terms of the receivables).

ary withholding certificates and certain presumptions available to withholding agents for purposes of treating a payee as foreign or domestic). 
With respect to the United States, a corporation will not be deemed engaged in a trade or business therein if it only effects transactions in stocks or securities for its own account; this is because there is a statutory safe harbor against being treated as so engaged if activities are limited to investment for one's own account. ${ }^{76}$ If, however, an SPV is buying many different obligations (including loans and loan participations) over a period of time, an issue arises as to whether the SPV would be viewed as engaged in some part of financing business; such a finding would remove the SPV from the protection of the investment safe harbor. To minimize this risk, certain guidelines should be observed, including, for example, restricting the SPV to buying loans in the secondary market rather than originating loans; not permitting the SPV to buy revolving facilities, which raise an issue of origination; not permitting negotiation of specific terms of loans; and/or prohibiting an SPV from receiving amounts denominated as fees that could be construed as having been received in return for performance of services.

If the SPV is a foreign corporation with U.S. shareholders, account must also be taken of certain so-called "anti-avoidance" provisions of the Internal Revenue Code. These include the Subpart F rules on "controlled foreign corporations" (CFCs), i.e. foreign corporations controlled by U.S. shareholders, and the "foreign personal holding company" and "passive foreign investment company" (PFIC) rules.

Under the Subpart $\mathrm{F}$ rules, ${ }^{77}$ certain earnings (including passive interest and dividend income) of U.S.-controlled foreign corporations may be treated as taxable to the U.S. shareholders even if not actually distributed. In addition, deemed dividends can result if a CFC's assets serve, either directly or indirectly, to secure a U.S. shareholder's debt; or if the debt is purchased or guaranteed by the CFC; or if twothirds or more of the CFC's stock is used to secure the debt. ${ }^{78}$ Thus, for example, if an SPV is a CFC and it buys receivables from a related U.S. originator in a tax loan transaction, Subpart $F$ issues could arise.

76. 26 U.S.C. $\$ 864($ b)(2)(A) (1994 \& Supp. 1999). Under prior law, this safe harbor treatment was available only if the "principal office" of the corporation were not in the United States. In determining the existence of a U.S. principal office, a corporation's U.S. and non-U.S. activities would be compared and if all or a substantial portion of certain enumerated functions (the so-called "ten commandments") were performed offshore, the safe harbor applied. Effective with respect to tax years beginning after December 31, 1997, the non-U.S. principal office requirement no longer applies. See 26 U.S.C. § 864(b)(2)(A)(ii) (1994 \& Supp. 1999).

77. 26 U.S.C. $\S \S 951-64$ (1994 \& Supp. 1999).

78. See 26 U.S.C. § 956(d) (1994); Treas. Reg. § 1.956-2(c) (1964). 
Under the foreign personal holding company rules, passive income of a closely-held SPV can be imputed to U.S. shareholders. This arises, however, only if the SPV is controlled, directly or indirectly, by five or fewer U.S. individuals. ${ }^{79}$

Under the PFIC rules, any U.S. shareholder of an SPV that is a PFIC (i.e., that has primarily passive income), whether or not the U.S. shareholders are in control, may be liable for an interest charge on dividend distributions from the SPV, unless an election is made either to recognize as dividends the SPV earnings on a current basis or, in the case of regularly traded PFIC stock, to take into account each year, under a mark-to-market regime, the built-in gain or loss attributable to the difference between the stock's current value and the shareholder's adjusted tax basis therein. ${ }^{80}$

3. "Earnings Stripping." Under the so-called "earnings stripping" rules of Section 163(j) of the Internal Revenue Code, a U.S. corporate borrower may be limited in the extent to which it can claim deductions on a current basis for interest expense. Interest expense subject to potential limitation under these provisions includes that on debt owed to related persons (including, in particular, related nonU.S. entities exempt from withholding tax under an applicable tax treaty) that are wholly or partially exempt from U.S. federal income $\operatorname{tax}^{81}$ or on debt guaranteed (whether via a formal guarantee or "comfort letter" or other arrangement) by such a person. ${ }^{82}$ The earnings stripping provisions apply if the corporation has a debt-to-equity ratio

79. See 26 U.S.C. $\S \S 551-58$ (1994 \& Supp. 1999).

80. See 26 U.S.C. $\$ \S 1291-98$ (1994 \& Supp. 1999). Under the mark-to-market election, a PFIC shareholder's adjusted basis in the PFIC stock will be increased by any amount previously included in income as a result of the election and decreased by any amounts allowed as a deduction thereby. 26 U.S.C. $§ 1296$ (b) (1994 \& Supp. 1999).

81. Interest that is subject to a reduced treaty rate of U.S. withholding tax is treated in part as not subject to U.S. tax in proportion to the applicable treaty's reduction of the U.S. statutory withholding tax rate. 26 U.S.C. § 163(j)(5)(B) (1994 \& Supp. 1999). For example, assuming the current U.S. statutory withholding tax rate of thirty percent, if the applicable treaty rate is fifteen percent, one-half of the interest paid or accrued to a resident of the treaty country will be considered as not subject to U.S. federal income tax.

82. The provisions with respect to guaranteed debt do not apply (i) to the extent provided in regulations, if the guarantor would have been subject to tax, on a net income basis, had interest been paid to it, or (ii) if the borrowing taxpayer owns at least eighty percent of the guarantor. A loan guaranteed by a foreign affiliate subject to a full U.S. withholding tax (as opposed to a net income tax) seemingly could, however, be subject to the earnings stripping rules. 
in excess of 1.5 to 1 and if its interest expense in a given taxable year exceeds a prescribed threshold. ${ }^{83}$

At least under current law, the earnings stripping rules should apply in cross-border securitization transactions only to the extent that the transaction involves a tax loan, as opposed to a sale, of receivables. This is because in a tax sale there is no interest expense. Although there then may be a loss on the sale of receivables, there is to date no provision treating such loss as interest expense for purposes of the earnings stripping provisions. This could change, however, if a loss on a sale of receivables were to be created, for purposes of the earnings stripping rules, as the equivalent of interest. Proposed regulations have, to date, reserved on this issue. ${ }^{84}$

If a transaction involves a tax loan, the earnings stripping rules could apply if, for example, the loan is guaranteed by a foreign parent of the originator/borrower. Only guarantees of underlying credit risk with respect to transferred receivables, however, as opposed to guarantees of performance or warranties as to the nature and quality of receivables, should trigger application of the earnings stripping rules in such cases.

4. Other Cross-Border Tax Issues. Other tax issues that may arise in cross-border securitizations include generation of currency gains or losses under I.R.C. Section 988, to the extent, for example, that a U.S. party to the transaction is entitled to receive (or required to pay) currency other than U.S. dollars; potential withholding tax on swap payments; ${ }^{86}$ and potential transfer price adjustments under

83. See 26 U.S.C. $§ 163(j)(2)$ (1994 \& Supp. 1999). Specifically, current interest deductions will be denied if the corporation's net interest expense in a given year exceeds fifty percent of its annual adjusted taxable income, which is its taxable income computed with certain adjustments, including ignoring net interest expense, any net operating loss deduction, or any depreciation, amortization or depletion deduction. Disallowed interest expense may be carried forward and deducted in the taxable year in which the corporation has net interest expense in an amount less than fifty percent of its adjusted taxable income.

84. See Proposed Treas. Reg. §§ 1.163(j)-2(e)(3), 56 Fed. Reg. 27907 (1991). Cf. Temp. Reg. $\$ 1.861-9 \mathrm{~T}(\mathrm{~b})(3)$ (1988) (losses on sale of certain receivables treated as equivalent to interest expense for purposes of source of income rules). The latter provision discouraged use of securitizations to maximize use by multi-national corporations of foreign tax credits by maximizing foreign source income.

85. The legislative history to Section $163(\mathrm{j})$ indicates that a guarantee for this purpose includes "any arrangement under which a person directly or indirectly assures, on a conditional or unconditional basis, the payment of another's obligation" under any indebtedness. See H.R. Rep. No. 103-111, at 686 (1993), reprinted in 1993 U.S.C.C.A.N. 378, 917.

86. For U.S. purposes, although Treas. Reg. $§ 1.863-7$ (1991) provides that swap payments to foreign counterparties do not generally constitute U.S. source income (and thus are not sub- 
I.R.C. Section 482, where sales or other transfers take place between affiliated parties in different jurisdictions. Transfer pricing issues could arise, for example, if there are multiple SPVs in different jurisdictions or if receivables being sold arise from sales between U.S. and non-U.S. affiliates.

Additionally, swaps and hedges may be subject to taxation. ${ }^{87}$ For example, gain or loss may have to be recognized based on fluctuations in the relative value of U.S. dollars and the currency of the assets. There also may be tax issues where transfers are among related entities, such as multiple SPVs in different jurisdictions.

\section{EPILOGUE}

My goal has been to provide an introduction to international securitization. Securitization has an increasingly international focus because, among other reasons, companies that wish to raise capital market funding may not be located in countries with established capital markets. They therefore must structure deals that cross their national borders.

Cross-border securitization, however, can be daunting to the uninitiated, involving multiple legal systems with strange terms and sometimes even stranger rules. I have argued that it is unnecessary for a securitization lawyer who does not regularly practice in foreign jurisdictions to keep up with changes in foreign legal systems. All that is needed is a grasp of certain fundamental legal principles in order to ask the right questions of local counsel and understand the re-

ject to U.S. withholding tax), non-periodic payments made to U.S. counterparties pursuant to a swap agreement may give rise to U.S. source interest income. Under Treas. Reg. §1.446-3(g)(4) (1994), a "significant" non-periodic payment is treated as a loan to the U.S. counterparty and the time value component associated with such loan must be recognized as U.S. source interest for all purposes of the Code. Although "significant" for these purposes is not defined, an example in the regulations provides that a non-periodic payment is significant if it exceeds forty percent of the present value of the fixed payments under the swap agreement. See Treas. Reg. § 1.446-3(g)(6) Example 3 (1993). Thus, if a swap agreement provides for a significant nonperiodic payment and the foreign counterparty cannot claim the benefits of the portfolio interest exemption or an applicable income tax treaty, the U.S. source interest income arising from the significant non-periodic payment will be subject to U.S. withholding tax at a rate of thirty percent. See Treas. Reg. § 1.1441-4(a)(3) (1997) (a withholding agent that pays amounts attributable to a notional principal contract described in Treas. Reg. $\$ 1.863-7$ (a) or $\S 1.988-2$ (e) shall have no obligation to withhold on amounts paid under the terms thereof, (but not including any amount treated as interest under Treas. Reg. $\S 1.446-3(\mathrm{~g})(1993))$ regardless of whether a withholding certificate is provided, but income will generally be treated as effectively connected with the conduct of a U.S. trade or business unless agent can rely on a withholding certificate to the contrary).

87. Cf. supra note 72 and accompanying text. 
sponse and its implications. This article has attempted to set forth those principles.

In the future, this communication may become even easier. As this symposium demonstrates, the laws and rules governing international securitization are being increasingly harmonized. For example, Spiros Bazinas's article, ${ }^{88}$ as well as this one, analyzes the United Nations Commission on International Trade Law's Convention on Assignment of Receivables in International Trade, designed to harmonize critical aspects of the laws applicable to cross-border securitization. Peter Jeffrey's article discusses international harmonization of accounting standards. ${ }^{89}$ And Professor Frankel generally examines the international unification of securitization law. ${ }^{90}$ With time and luck, one day we may well be able to converse about international securitization through a true "universal language."

88. Bazinas, supra note 16.

89. Jeffrey, supra note 28.

90. Tamar Frankel, The Law of Cross-Border Securitization: Lex Juris, 12 DuKE J. COMP. \& INT’L L. 475 (2002). 